\title{
Differences between Traditional and Augmented-Reality Experiential Marketing Campaigns
}

\author{
Yu-Hsuan Lin \\ Graduate School of Creative Industry Design \\ NTUA University, Taiwan \\ Ming-Chuan Fu \\ Communication Design \\ NTUA University, Taiwan \\ Po-Hsien Lin \\ Graduate School of Creative Industry Design \\ NTUA University, Taiwan
}

\begin{abstract}
This research investigated differences in experiential marketing campaigns after companies applied augmented reality to experiential marketing strategies. This study used case studies to analyze traditional and augmented reality experiential campaigns.
\end{abstract}

Keywords: experiential marketing, augmented reality

\section{Introduction}

Retail environments have been transformed by the introduction of electronic operations and rapid hardware. Traditional retailers have begun using these to complement their marketing strategies (Pascale, 2000). Experience is the result of encounters, and it simulates an event for use in marketing before and after purchases (McLuhan, 2008). The rapid evolution of technology has allowed online retailers to defeat local retailers for years. In 2012, business-to-consumer ecommerce sales grew $21.1 \%$ and topped US\$1 trillion worldwide for the first time (eMarker, 2013). Most retailers have begun to apply experiential marketing. Merging shopping and augmented reality (AR) can provide consumers with different purchase experiences regardless of their location. Unlike traditional shopping, online shopping depends on the Internet, and thus online retailers can provide services or contact their consumers indirectly. However, consumers now expect memorable shopping experiences (Cyr, 2000; Pine \& Gilmore, 1999).

\section{Literature Review}

\subsection{Experiential Marketing}

Experiential marketing, based on allowing customers to undergo an experience through motion (Snakers \& Zajdman, 2010), aims to create emotions for customers' enjoyment and affect their attitude toward purchase choices. Experiential marketing involves a face-to-face communication method (You Ming, 2010). Customer recognition and purchases enhance the value of a brand. Experiential marketing involves five strategic dimensions, namely sensual, emotional, cognitive, active, and relational experiences (Schmitt, 1999), and is used to interact with customers and directly harness their emotions, feelings, and senses.

Consumption experience can enrich the brand value. Experiential value based on interactions results in preferences by certain customers (Holbrook \& Corfam, 1985). The typology of experiential value constructed by Holbrook in 1994 classified value into four items framed by intrinsic, extrinsic, active, and reactive values (Fig. 1).

\begin{tabular}{|c|c|c|}
\hline Intrinsic Value & Playfulness & Aesthetics \\
\hline Extrinsic Value & $\begin{array}{l}\text { Consumer } \\
\text { Return } \\
\text { Investment }\end{array}$ & $\begin{array}{l}\text { Service } \\
\text { Excellence }\end{array}$ \\
\hline
\end{tabular}

Fig. 1 Typology of experiential values 
The five types of customer experiences - sensual, emotional, cognitive, active, and relational experiences - construct the basis of an experiential marketing framework. Sensual experiences contain three parts: stimuli, processes, and consequences (Schmitt, 1999).

\subsection{AR}

AR is the technology that combines real-time and virtual images. AR was coined by Thomas Preston Caudell, a Boeing researcher, in 1992 (Caudell \& Mizell, 1992). The first presentation of AR appeared in an issue of Communication of the ACM in July 1993 (Höllerer \& Feiner, 1999), AR was considered a technology merging electronic systems with the physical environment instead of replacing it. AR opposes the concept of virtual reality, which immerses users in a virtual environment completely composed by a computer. AR uses the real-time camera position and angle to integrate digital images to include three-dimensional (3D) animation, video, and physical spaces for interaction. In 1997, Milgram defined a continuum of real to virtual environments, and AR is located in the "Mixed Reality" area (Fig. 2).

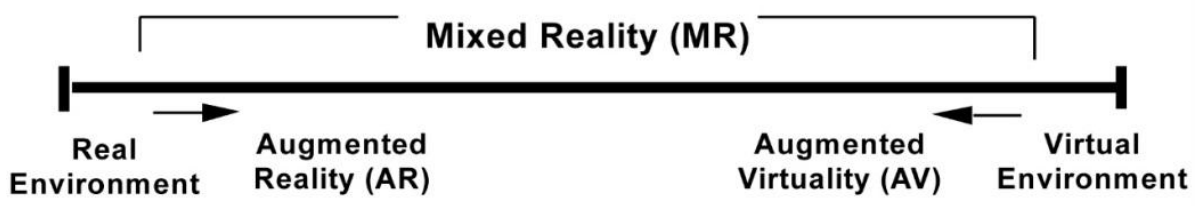

Fig. 2 Milgram's Reality-Virtuality Continuum

The surrounding environment in virtual environments and augmented virtuality are virtual, whereas the surrounding environment used in AR is real.

The field of AR has been existent over a decade and has quickly grown over the past few years. The definition of AR can be shortened to the following:

(1) Blending of the real and the virtual in a real environment

(2) Real-time interaction

(3) Application of portable devices

This definition is not limited to particular display devices, such as Oculus virtual reality headsets. AR has now matured and receives considerable attention. Furthermore, the rapid growth of smart phones allows AR to be designed with fewer restrictions. AR greatly changed after smart phones were developed, and people with smart phones can now experience AR everywhere.

\subsection{Immersion Experience}

Immersion is one of the most crucial elements of AR. Nowadays, AR is used in business marketing to increase brand value. Designers focus on methods of immersing users in AR projections as much as possible. Immersion is a "flow experience," which positive psychologists call "being in the zone" (Csikszentmihalyi, 2002). Immersion allows people to focus on a target built by designers to feel pleasure and satisfaction and forget the real world. Flow is the mental state of operation in which a person is fully immersed in performing an activity and feels energized, which results in the person's full involvement and enjoyment in the activity (Csikszentmihalyi, 2002). Flow experience is the best experience you exactly what it is in our current challenges and their ability to match the state. People can achieve immersion in their current situation and forget their real-world situation. However, the immersive state of mind is not limited to games. Immersive experiences often include human sensory and cognitive experiences (Jennett, 2008).

According to this narrative, any design used for immersion can be considered an immersive design. The common rule of immersive design is as follows:

- Narrative designs use situations, roles, the atmosphere, and the rhythm to allow audiences to enter the story.

- People should be able to achieve goals with minimal effort, few cognitive obstacles, and little motion resistance.

\section{AR Applications in Experiential Marketing}

This study analyzed the actualities and relationship between experiential values and AR for experiential marketing. In recent years, AR has changed into a portable technology and has influenced marketing methods.

This research focuses on experiential marketing methods that apply AR technology and define a new model of experiential marketing. This study used case studies to analyze differences between traditional and AR experiential marketing.

\subsection{Example of Experiential Marketing}


Previous experiential marketing strategies focused on sensual, emotional, cognitive, active, and relational experiences. The marketer incorporates visual images, product presence, and brand identity into activities aimed at making people participate to develop an interest in the product. This encourages people to develop a stronger impression after the experience. Experiential marketing can involve holding expos or campaigns to spur customers to talk about the business or product.

Table 1. Experiential marketing samples

\begin{tabular}{l|l|l}
\hline $\begin{array}{l}\text { Campaign } \\
\text { title }\end{array}$ & Sample image & $\begin{array}{l}\text { Concept } \\
\text { Coke came up with this concept of sharing cans. } \\
\text { Each can into two smaller cans. }\end{array}$ \\
\hline $\begin{array}{l}\text { Coca-Cola } \\
\text { Adidas and Can }\end{array}$ & $\begin{array}{l}\text { Chicago Bulls point guard Derrick Rose was in } \\
\text { attendance to challenge fans to win a pair of free } \\
\text { trainers by taking them off a shelf that happened } \\
\text { to be 10 foot in the air. }\end{array}$ \\
\hline $\begin{array}{l}\text { Heineken The Rose } \\
\text { Last Ticket }\end{array}$ & $\begin{array}{l}\text { Sing the UEFA Champions League Anthem in } \\
\text { front of everybody and get a VIP Backstadium } \\
\text { Pass and the last few tickets for the UEFA } \\
\text { Champions League game. }\end{array}$ \\
\hline
\end{tabular}

Table 2. Experiential marketing samples

\begin{tabular}{|c|c|c|c|}
\hline Campaign title & Experiential subject & $\begin{array}{l}\text { Experiential } \\
\text { strategy }\end{array}$ & $\begin{array}{l}\text { Experiential } \\
\text { equipment }\end{array}$ \\
\hline Coca-Cola Sharing Can & Individual person & Feel, Sense, Act & $\begin{array}{l}\text { Coca cola vending } \\
\text { machines }\end{array}$ \\
\hline Adidas and Derrick Rose & Individual person & Sense, Feel & Derrick Rose house \\
\hline Heineken The Last Ticket & Individual person & Feel, Sense, Act & $\begin{array}{l}\text { Heineken music } \\
\text { equipment }\end{array}$ \\
\hline
\end{tabular}

By using the aforementioned narrative, we could analyze the experiential strategies of various cases. The strategy experience types were classified on the basis of Bernd Schmitt.

Table 3. Experiential strategy analysis

\begin{tabular}{l|l|l|l}
\hline $\begin{array}{l}\text { Campaign } \\
\text { title }\end{array}$ & $\begin{array}{l}\text { Experiential } \\
\text { strategy }\end{array}$ & Strategy experiences & Interactive \\
\hline $\begin{array}{l}\text { Coca-Cola } \\
\text { Sharing Can }\end{array}$ & $\begin{array}{l}\text { Feel, Sense, } \\
\text { Act }\end{array}$ & $\begin{array}{l}\text { Positive emotion, Inward emotion, } \\
\text { Nonverbal behavior, self-perception, } \\
\text { flesh }\end{array}$ & $\begin{array}{l}\text { Human-machine } \\
\text { interact, Reality } \\
\text { environment }\end{array}$ \\
\hline $\begin{array}{l}\text { Adidas and } \\
\text { Derrick Rose }\end{array}$ & Feel, Sense & Positive emotion, Outward emotion, & $\begin{array}{l}\text { Human-human } \\
\text { interact, Reality } \\
\text { environment }\end{array}$ \\
\hline $\begin{array}{l}\text { Heineken The } \\
\text { Last Ticket }\end{array}$ & $\begin{array}{l}\text { Feel, Sense, } \\
\text { Act }\end{array}$ & $\begin{array}{l}\text { Positive emotion, Outward } \\
\text { emotion,Nonverbal behavior, self- } \\
\text { perception, lifestyle, flesh }\end{array}$ & $\begin{array}{l}\text { Human-machine } \\
\text { interact, Reality } \\
\text { environment }\end{array}$ \\
\hline
\end{tabular}

\subsection{Example of AR Experiential Marketing}

Media technology and smart phones have changed e-commerce marketing. Websites are not the main method of spreading information and rarely interact with customers.

Social networking and multimedia sharing platforms have become the largest marketing fields. Hence, we adopted AR experiential campaigns from the same aforementioned brands.

\section{Table 4. AR experiential marketing samples}




\begin{tabular}{l|l|l}
\hline Campaign title & Concept \\
\hline $\begin{array}{l}\text { Coca-Cola Open } \\
\text { happiness }\end{array}$ & $\begin{array}{l}\text { Coca-Cola Open happiness } \\
\text { augmented reality experience } \\
\text { at Positivus 2012. }\end{array}$ \\
\hline $\begin{array}{l}\text { Adidas Originals DJ } \\
\text { game with shoe as } \\
\text { controller }\end{array}$ & $\begin{array}{l}\text { Adidas Originals launched } \\
\text { the DJ Augmented Reality } \\
\text { experience in footwear. }\end{array}$ \\
\hline $\begin{array}{l}\text { Street marketing } \\
\text { Heineken Open }\end{array}$ & $\begin{array}{l}\text { Interact with virtual character } \\
\text { and project at the screen at } \\
\text { Taiwan. }\end{array}$ \\
\hline
\end{tabular}

Table 5. AR experiential marketing samples

\begin{tabular}{l|l|l|l}
\hline Campaign title & Experiential subject & $\begin{array}{l}\text { Experiential } \\
\text { strategy }\end{array}$ & $\begin{array}{l}\text { Experiential } \\
\text { equipment }\end{array}$ \\
\hline Coca-Cola Open happiness & Individual person & $\begin{array}{l}\text { Feel, Sense, } \\
\text { Act }\end{array}$ & Projection \\
\hline $\begin{array}{l}\text { Adidas Originals DJ game with } \\
\text { shoe as controller }\end{array}$ & Individual person & Sense, Feel & PC \\
\hline $\begin{array}{l}\text { Street marketing Heineken } \\
\text { Open Your world }\end{array}$ & Individual person & $\begin{array}{l}\text { Feel, Sense, } \\
\text { Act }\end{array}$ & Projection \\
\hline
\end{tabular}

Table 6. AR experiential strategy analysis

\begin{tabular}{l|l|l|l}
\hline Campaign title & $\begin{array}{l}\text { Experiential } \\
\text { strategy }\end{array}$ & Strategy experiences & Interactive \\
\hline $\begin{array}{l}\text { Coca-Cola Open } \\
\text { happiness }\end{array}$ & $\begin{array}{l}\text { Feel, Sense, } \\
\text { Act }\end{array}$ & $\begin{array}{l}\text { Positive emotion, Inward } \\
\text { emotion, Nonverbal behavior, } \\
\text { self-perception, flesh }\end{array}$ & $\begin{array}{l}\text { Human-virtual } \\
\text { interact, } \\
\text { Augmented reality }\end{array}$ \\
\hline $\begin{array}{l}\text { Adidas Originals } \\
\text { DJ game with } \\
\text { shoe as controller }\end{array}$ & Feel, Sense & $\begin{array}{l}\text { Positive emotion, Outward } \\
\text { emotion, }\end{array}$ & $\begin{array}{l}\text { Human-virtual } \\
\text { interact, } \\
\text { Augmented reality }\end{array}$ \\
\hline $\begin{array}{l}\text { Street marketing } \\
\text { Heineken Open } \\
\text { Your world }\end{array}$ & $\begin{array}{l}\text { Act Sense, } \\
\text { Ant }\end{array}$ & $\begin{array}{l}\text { Positive emotion, Outward } \\
\text { emotion, Nonverbal behavior, } \\
\text { self-perception, lifestyle, flesh }\end{array}$ & $\begin{array}{l}\text { Human- } \\
\text { virtualinteract, } \\
\text { Augmented reality }\end{array}$ \\
\hline
\end{tabular}

\section{Research Results}

Effective traditional or AR experiential marketing campaigns had the following common elements:

\section{(1) Product insertion into the campaign}

Experiential marketing entertains people and transforms them into potential customers. Therefore, inserting product information or the brand spirit properly is key.

(2) Creativity as the main goal

Whether campaigns are fun determines whether people develop an impression of the product. To make campaigns as interesting as possible, designers must use creativity in their designs.

(3) Crowd attraction 
Attracting a crowd of spectators can aid in promoting a campaign or presenting a product. Not everyone needs to participate in the event to leave an impression on passers-by.

(4) Easy use

Early in a campaign, the designer should set clear and simple instructions for people to follow the required steps. Most of the experiential marketing is located in the public. If people become frustrated or feel confused, they will not try the activity again.

According to an Allied Business Intelligence study in 2010, handheld platforms have transformed the AR advertising system, with revenue growing from approximately US\$6 million in 2008 to more than US\$350 million in 2014. The potential applications of mobile AR can be further enhanced by using them in various combinations. The aforementioned cases indicate differences between traditional and AR experiential marketing.

(1) Few geographical restrictions

AR technology relies on $\mathrm{C}$ or $\mathrm{C}++$, which allows it to be displayed through hi-tech equipment such as smart phones, computers, and multimedia projections. The Internet allows for instant communication, regardless of the geographical distance. Therefore, companies can conduct campaigns with AR anywhere simultaneously.

(2) Low cost

Compared to traditional campaigns, AR only requires a mark to track and display content on screens (such as smart phones or computers). Designers do not need to produce physical display objects for the campaign. Thus, companies can save considerable money.

(3) Modifiability

Because physical objects are not necessary for campaigns, AR is more modifiable. Furthermore, it is easy to copy and reproduce.

(4) Adoption by small and medium enterprises

Because it is less costly, AR can be used for experiential marketing through various methods. In the past, campaigns were always set by chain companies. Small or medium-sized enterprises can now also hold experiential campaigns.

\section{Conclusion}

Schmitt noted that experiential marketing has five factors for constructing experiential grids are sensual, emotional, cognitive, relational, and active experiences in the experiential marketing theory developed in 1995. However, the current Internet-based environment substantially differs from that in 1995. Nevertheless, based on the aforementioned five elements, this research observed some current factors.

\subsection{Virtual Amusement}

AR can be classified into two types of user interaction:

(1) Surface display

This type of display can only present virtual images by using tracking marker. People can often only view 3D virtual reality displays available in $360^{\circ}$ or as virtual animation. However, such a display cannot interact more with people. The technology is not easy to create; thus, people are still entertained by it.

(2) Mutual display

This type of display is more difficult than surface display. The designer must detect hand gestures or other types of motion capture to include virtual reality elements. People can view images and interact with the virtual reality campaign. The experience combines feelings used for traditional campaigns and new technology.

\subsection{Personal Participation}

AR can be delivery everywhere, and even campaigns can be experienced in private areas. Companies do not need to set physical object in public, which hinders campaigns from attracting crowds. If all experiential marketing uses the private individual method, audiences may disappear eventually.

\subsection{Social Network Inclusion}

Social networking sites, such as Facebook, Twitter, Line, and Instagram, transform people's lives and marketing strategies. "Viral marketing" has entered the e-marketing field and has thus become a common Internet marketing method, often for website promotion or brand promotion. Given the appeal of social networking, viral marketing can be combined with AR experiential marketing. People who experience something new post it on social networking sites to inform others.

AR experiential marketing can be recorded and uploaded on the Internet simply, and thus, companies do not need to advertise products because participants propagate them automatically.

This study. 
Incorporation of AR has become a new trend in experiential marketing. Although AR platform technology is not yet as mature as web-based technology, this niche and novel display modus will influence experiential marketing in the future.

\section{References}

Milgram, P. \&Kishino, F. (1997).A taxonomy of mixed reality visual display. IEICE Trains Information Systems. Vol. E77-d,1321-1329

Charla, M. \&Naresh, M. (2000). Experiential value: conceptualization, measurement and application in the catalog and internet shopping environment. Journal of Retailing, 77,39-56.

Roland, A. \&Yohan, B. \& Reinhold, B. (2001). Recent advances in augmented reality. Computer \& Graphics. 1-11

Bernd, H. S. (1999). Experiential Marketing.The Free Press. New York, USA.

Bernd, H. S. \& Alex, S. (1997). The strategic management of brands, identity and image.The Free Press. New York, USA.

Steven, P. (1997). How the mind works. Norton, New York, USA.

Mihaly, C. (2008). Flow: The Psychology of Optimal Experience. Harper Collins, USA.

Azuma, R. (1997). Teleoperators and virtual environments.A survey of augmented reality in presence. Vol.6, 355-385.

Perey, C. (2011).Print and publishing and the future of augmented reality.

Camba, J. (2014). Visualization and Engineering Design Graphics With Augmented Reality. Schroff Development Corp, USA.

Alan, B. (2013). Understanding Augmented Reality: Concepts and Applications. Elsevier Science Ltd, USA.

Ann M. \&Alessandro M. \&Saija L. \&Antti O. \&Giulio J. \& Peter P. \& Dieter S. \&Holger R. (2011). Collaborative use of mobile augmented reality with paper maps. Vol 35, Issue 4, August 2011, Pages 789-799 